\title{
THE SPECIES COMPOSITION OF ROTIFERS IN THREE HYDROELECTRIC RESERVOIRS OF WESTERN HIGHLANDS, CENTRAL VIETNAM
}

\author{
Duong Quang Hung1, Phan Nhat Truong1, Vo Van Minh ${ }^{1,2}$, \\ Tran Nguyen Quynh Anh ${ }^{1,3}$, Trinh Dang Mau ${ }^{1,2, *}$ \\ ${ }^{1}$ DN-EBR Research Group, The University of Da Nang, Da Nang, Vietnam \\ ${ }^{2}$ Facuty of Biology and Environmental Science, The University of Da Nang, \\ University of Science and Education, Da Nang, Vietnam \\ ${ }^{3}$ Facuty of Chemistry, The University of Da Nang, University of Science and Education, \\ Da Nang, Vietnam
}

Received 19 July 2020, accepted 25 February 2021

\begin{abstract}
The rotifer fauna in three hydroelectric reservoirs of western highlands, central Vietnam were studied. Among a total of 63 identified species and subspecies, beloging to 23 genera in 15 families, Brachionidae was the most diverse family with 15 taxa recorded $(23.81 \%)$ followed by Lecanidae (14 taxa, 22.22\%), and Synchaetidae (8 taxa, 12.7\%). Species accumulation curve and species richness estimators suggested a relatively high level of biodiversity of rotifera assemblages in the studied area. Besides, results on species composition of rotifera community in this study were compared to those of other freshwater bodies in Vietnam using Jaccard similarity index. In particular, the highest similarity was found between reservoirs in western highlands and Phu Ninh lake, Quang Nam Province while the largest difference in species composition was observed between western highlands and Bau Thiem lake, Thua Thien Hue Province.
\end{abstract}

Keywords: Rotifera, species richness, zooplankton, Western highlands.

Citation: Duong Quang Hung, Phan Nhat Truong, Vo Van Minh, Tran Nguyen Quynh Anh, Trinh Dang Mau, 2021. The species composition of rotifers in three hydroelectric reservoirs of western highlands, Central Vietnam. Academia Journal of Biology, 43(1): 53-60. https://doi.org/10.15625/2615-9023/15295

*Corresponding author email: trinhdangmau@gmail.com

(C2021 Vietnam Academy of Science and Technology (VAST) 


\section{INTRODUCTION}

Rotifers have universal distribution and account for a large proportion of zooplankton in water bodies, playing a substantial part in the functioning of ecosystems. These animals contribute considerably to the biodiversity of water bodies in the tropical and equatorial climate zones (Dussart et al., 1984).

The phylum Rotifera comprises about 2030 known species classified in three main groups, the marine Seisonida (3 species) the Monogononta (1570 species) and the unique, exclusively parthenogenetic Bdelloidea with 461 clonal species (Segers, 2007). In Vietnam, the first record of rotifera was reported by Shirota (1966) with 72 species in freshwater and 6 species in saline water. Dang et al. (1980) identified 52 species of rotifers in freshwater bodies in Northern Vietnam. Studies after that recorded 65 species in central Vietnam (Zhdanova, 2011) and 49 species in Southern Vietnam (Dang, 2012). Most notably, recent studies conducted by Trinh-Dang et al. (2019a, 2019b, 2015, 2013) documented 100 new records to Vietnam's rotifer fauna and five new species to science.
These results indicate a high potential of rotifer diversity in Vietnam.

Western highlands comprising five provinces, Kon Tum, Gia Lai, Dak Lak, Dak Nong and Lam Dong, is one of three subregions in central Vietnam. The region is mostly covered by forests which retain many water bodies with diverse biological resources. In order to explore the biodiversity Western Highlands as well as to contribute deeper knowledge about rotifera communities in Vietnam, a study on species composition of rotifers in three hydroelectric reservoirs, which currently play an important role in supplying water and hydroelectric power for human consumption as well as agricultural and industrial activities, was conducted.

\section{MATERIALS AND METHODS}

Three hydroelectric reservoirs located on the border between Dak Lak Province and Dak Nong Province, namely Serepok, Buon Kuop, and Buon Tua Srah, were investigated in September 2016, (Fig. 1). These reservoirs are positioned in The Serepok river basin, a $400 \mathrm{~km}$ tributary of the Mekong river with a total basin area of approximately $30.100 \mathrm{~km}^{2}$.

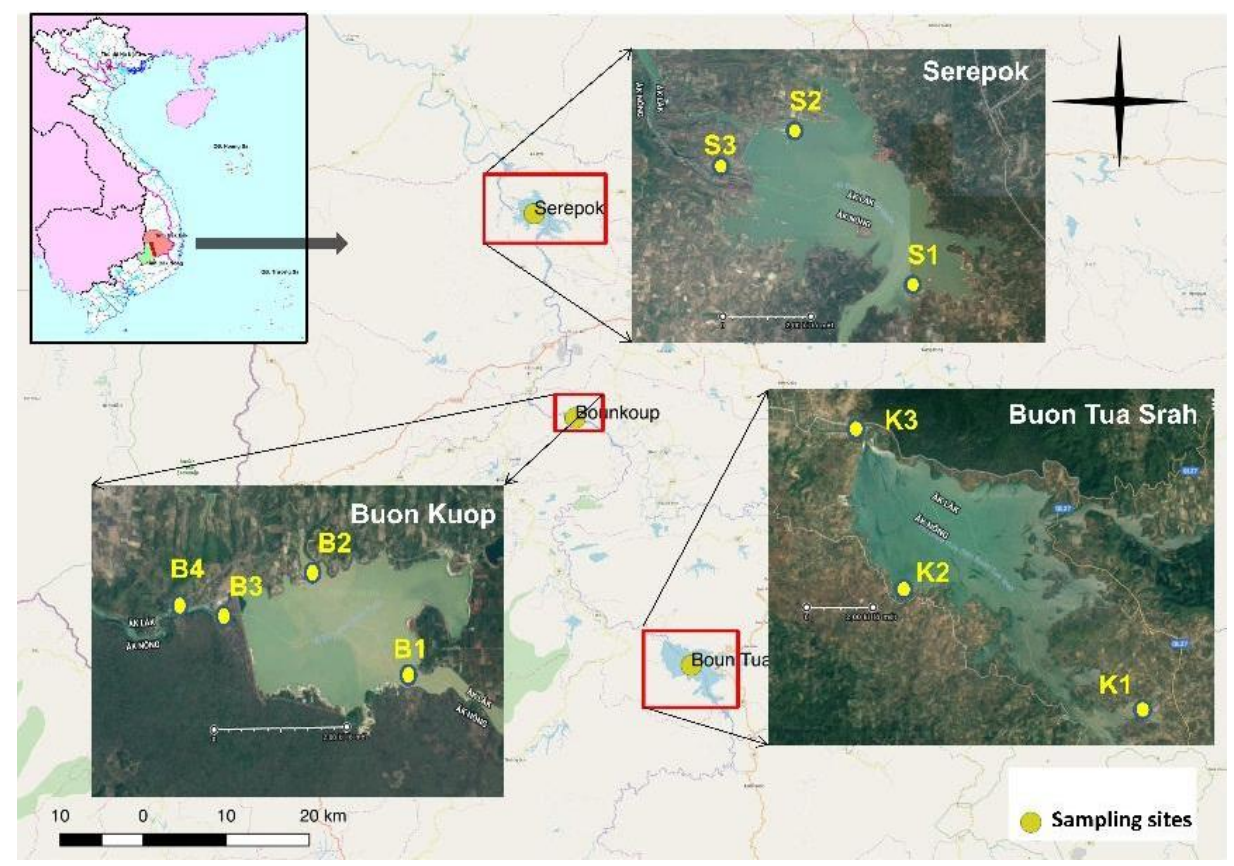

Figure 1. Schematic map of the study area 
Zooplankton was studied in the littoral zone of reservoirs. Qualitative samples of rotifers were collected using a $50 \mu \mathrm{m}$ mesh size cast-net and immediately preserved in $4 \%$ formaldehyde. Rotifer specimens were sorted and examined using a Hund (H600) compound microscope equipped with a camera. The trophi of rotifers were examined by adding a drop of commercial sodiumhypochlorite $(\mathrm{NaOCl})$ to dissolve and isolate the hard trophi parts. Identification was based on taxonomy and nomenclature of the rotifers as in Segers (2007). The species accumulator, species richness estimators and similarity index were calculated using the vegan package (Oksanen et al., 2013) in $\mathrm{R}$ (Team, 2013). Of these, Jacknife 2 and Chao 2 estimators were selected to estimate the expected diversity of rotifer in reservoirs (Trinh-Dang et al., 2019b). $\mathrm{Q}_{\mathrm{B} / \mathrm{T}}$ index was used to evaluate the nature of eutrophic conditions:

$$
Q_{B / T}=\frac{\text { No.of Brachionus sp. }}{\text { No.of Trichocerca sp. }}(\text { Sládeček, 1983) }
$$

\section{RESULTS AND DISCUSSION}

A total of 63 species and subspecies of 23 genera belonging to 15 families were identified in the studied area. Checklist is provided in Table 1. Of these, Brachionidae was the most diverse family with 15 taxa recorded $(23.81 \%)$ followed by Lecanidae (14 taxa, 22.22\%), Synchaetidae (8 taxa, 12.7\%) and Trichocercidae (7 taxa, 11.11\%) (Fig. 2).

Table 1. Checklist of rotifer species of the studied reservoirs

\begin{tabular}{|c|c|c|c|c|}
\hline \multirow{2}{*}{ No. } & \multirow{2}{*}{ Taxon } & \multicolumn{3}{|c|}{ Reservoir } \\
\hline & & (1) & (2) & (3) \\
\hline \multicolumn{5}{|c|}{ Collothecidae } \\
\hline 1 & Collotheca ornata (Ehrenberg, 1830) & + & + & + \\
\hline \multicolumn{5}{|c|}{ Conochilidae } \\
\hline 2 & Conochilus dossuarius Hudson, 1885 & + & + & + \\
\hline 3 & Conochilus unicornis Rousselet, 1892 & + & + & + \\
\hline \multicolumn{5}{|c|}{$\begin{array}{ll}\text { Flosculariidae } \\
\end{array}$} \\
\hline 4 & Floscularia bifida Segers, 1997 & & & + \\
\hline \multicolumn{5}{|c|}{ Hexarthridae } \\
\hline 5 & Hexarthra mira (Hudson, 1871) & + & + & + \\
\hline \multicolumn{5}{|c|}{ Testudinellidae } \\
\hline 6 & Testudinella patina (Hermann, 1783) & + & + & + \\
\hline \multicolumn{5}{|c|}{ Trochosphaeridae } \\
\hline 7 & Filinia camasecla Myers, 1938 & + & & \\
\hline 8 & Filinia longiseta (Ehrenberg, 1834) & + & & \\
\hline 9 & Filinia opoliensis (Zacharias, 1898) & + & + & + \\
\hline \multicolumn{5}{|c|}{ Asplanchnidae } \\
\hline 10 & Asplanchna priodonta Gosse, 1850 & + & + & + \\
\hline \multicolumn{5}{|c|}{ Brachionidae } \\
\hline 11 & Anuraeopsis coelata Beauchamp, 1932 & & + & \\
\hline 12 & Anuraeopsis fissa (Gosse, 1851) & + & + & + \\
\hline 13 & Anuraeopsis navicula Rousselet, 1911 & + & & + \\
\hline
\end{tabular}




\begin{tabular}{|c|c|c|c|c|}
\hline 14 & Brachionus angularis Gosse, 1851 & + & + & + \\
\hline 15 & Brachionus caudatus Barrois \& Daday, 1894 & + & & + \\
\hline 16 & Brachionus dichotomus Shephard, 1911 & & + & + \\
\hline 17 & Brachionus falcatus Zacharias, 1898 & + & & \\
\hline 18 & Brachionus forficula Wierzejski, 1891 & + & + & + \\
\hline 19 & Brachionus quadridentatus Hermann, 1783 & & + & + \\
\hline 20 & Keratella cochlearis (Gosse, 1851) & & + & + \\
\hline 21 & Keratella cochlearis cochlearis (Gosse, 1851 ) & + & & \\
\hline 22 & Keratella lenzi Hauer, 1953 & & + & + \\
\hline 23 & Keratella tropica (Apstein, 1907) & + & + & + \\
\hline 24 & Plationus patulus (Müller, 1786) & + & + & + \\
\hline 25 & Platyias quadricornis (Ehrenberg, 1832) & & + & + \\
\hline \multicolumn{5}{|c|}{ Gastropodidae } \\
\hline 26 & Ascomorpha ecaudis Perty, 1850 & + & + & + \\
\hline 27 & Ascomorpha ovalis (Bergendal, 1892) & + & + & + \\
\hline \multicolumn{5}{|c|}{ Lecanidae } \\
\hline 28 & Lecane arcula Harring, 1914 & + & & + \\
\hline 29 & Lecane bulla (Gosse, 1851$)$ & + & + & + \\
\hline 30 & Lecane closterocerca (Schmarda, 1859) & & + & + \\
\hline 31 & Lecane crepida Harring, 1914 & & + & + \\
\hline 32 & Lecane curvicornis (Murray, 1913) & & + & \\
\hline 33 & Lecane hamata (Stokes, 1896) & & + & + \\
\hline 34 & Lecane hornemanni (Ehrenberg, 1834) & + & + & + \\
\hline 35 & Lecane leontina (Turner, 1892) & & + & + \\
\hline 36 & Lecane luna (Müller, 1776) & & + & + \\
\hline 37 & Lecane lunaris (Ehrenberg, 1832) & & + & + \\
\hline 38 & Lecane papuana (Murray, 1913) & & + & + \\
\hline 39 & Lecane quadridentata (Ehrenberg, 1830) & & + & + \\
\hline 40 & Lecane rhenana Hauer, 1929 & & + & + \\
\hline 41 & Lecane signifera (Jennings, 1896) & & + & + \\
\hline \multicolumn{5}{|c|}{ Lepadellidae } \\
\hline 42 & Colurella uncinata bicuspidata (Ehrenberg, 1830) & & + & + \\
\hline 43 & Lepadella ehrenbergii (Perty, 1850) & + & + & + \\
\hline 44 & Lepadella ovalis (Müller, 1786) & & + & + \\
\hline 45 & Lepadella patella (Müller, 1773) & & + & + \\
\hline \multicolumn{5}{|c|}{ Notommatidae } \\
\hline 46 & Cephalodella sp. & & + & + \\
\hline \multicolumn{5}{|c|}{ Synchaetidae } \\
\hline 47 & Ploesoma asiaticum Trinh Dang, Segers \& Sanoamuang, 2013 & & + & \\
\hline 48 & Ploesoma hudsoni (Imhof, 189) & + & + & + \\
\hline 49 & Ploesoma lenticulare Herrick, 1885 & & + & + \\
\hline 50 & Ploesoma sp. & + & + & \\
\hline 51 & Polyarthra dolichoptera Idelson, 1925 & + & + & + \\
\hline 52 & Polyarthra vulgaris Carlin, 1943 & + & + & + \\
\hline
\end{tabular}




\begin{tabular}{|c|c|c|c|c|}
\hline 53 & Synchaeta sp. & & + & + \\
\hline 54 & Synchaeta stylata Wierzejski, 1893 & + & + & + \\
\hline \multicolumn{5}{|c|}{ Trichocerca } \\
\hline 55 & Trichocerca capucina (Wierzejski \& Zacharias, 1893) & + & + & + \\
\hline 56 & Trichocerca chattoni (Beauchamp, 1907) & & + & + \\
\hline 57 & Trichocerca cylindrica (Imhof, 1891) & + & + & + \\
\hline 58 & Trichocerca dixonnuttalli (Jennings, 1903) & & + & + \\
\hline 59 & Trichocerca flagellata Hauer, 1937 & + & & + \\
\hline 60 & Trichocerca pusilla (Jennings, 1903) & & + & + \\
\hline 61 & Trichocerca similis (Wierzejski, 1893) & & + & + \\
\hline \multicolumn{5}{|c|}{ Trichotriidae } \\
\hline 62 & Macrochaetus collinsii (Gosse, 1867) & + & + & + \\
\hline 63 & Trichotria tetractis caudata (Lucks, 1909) & & + & + \\
\hline
\end{tabular}

Note: (+) species present; (1) Serepok; (2) Buon Kuop; (3) Buon Tua Srah.

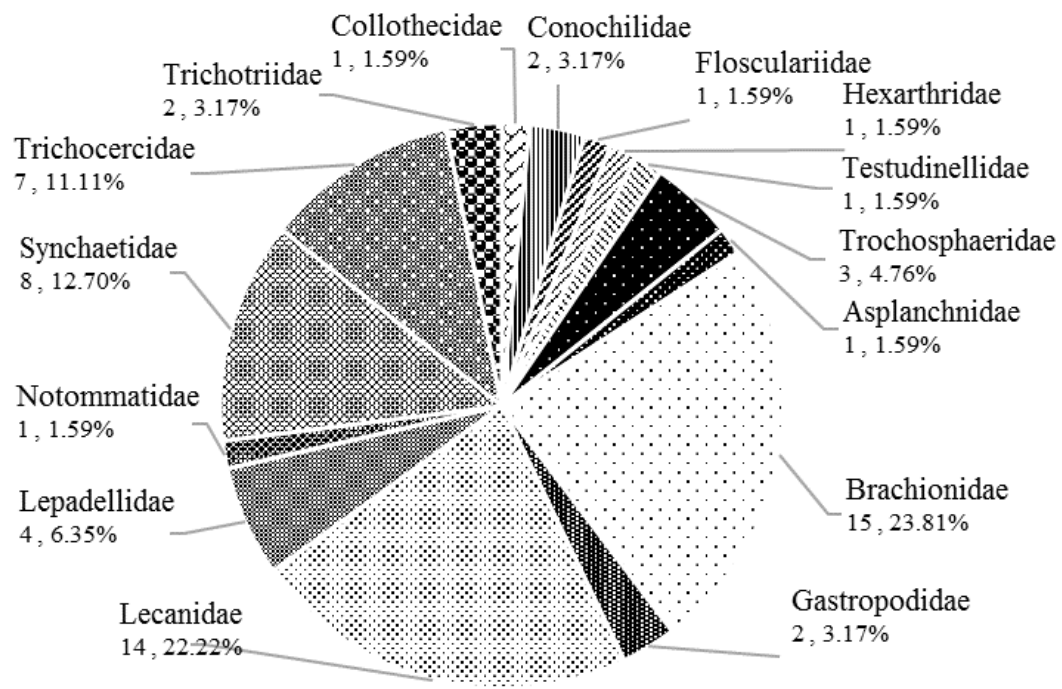

Figure 2. Composition of Rotifera community at family level in the studied reservoirs

One typical feature of the tropical rotifer fauna in southeast Asia is the prevalence of the families Brachionidae, Lecanidae, and Trichocercidae in terms of the number of species. In the pelagic zone, the family Brachionidae is prevalent while Lecanidae tends to dominate the littoral part (Dussart et al., 1984; Segers, 2001).

Regarding the number of recorded species in each reservoir, 34 taxa were found in Serepok reservoir, being lowest among the three investigated aquatic bodies, accounting for $53.97 \%$ total identified species in this area. Buon Kuop reservoir and Buon Tua Srah reservoir shared similar values with 54 and 55 species respectively (equivalent to $85.71 \%$ and $87.3 \%$ ) (Table 2).

The species composition of rotifers in the studied area in the western highlands (63 taxa belonging to 23 genera and 15 families) was quite similar to those of reservoirs in Khanh Hoa Province (Zhdanova, 2011) and Phu Ninh lake (Trinh-Dang et al., 2019b), where 61 - 65 taxa belonging to 15 families of rotifers were reported with the dominance of 2 families, Brachionidae and Lecanidae. This is possibly due to the similarities in geographical features and environmental characteristics. The species 
richness of the in this study was lower compared to those in some other freshwater bodies, such as Bau Thiem lake (89 taxa), Thuy Tien lake (82 taxa) in Thua Thien Hue Province, central Vietnam (Trinh-Dang et al., $2015,2013)$ and Kud-thing lake (183 taxa) in
Nong Khai Province, northeast Thailand (Sanoamuang and Savatenalinton, 2001). However, in comparison with freshwater bodies in southern Vietnam, with total taxa of 49 (Phan and Le, 2012), found a higher level of species richness was found in this study.

Table 2. Taxon of rotifer species in each study reservoirs

\begin{tabular}{|l|c|c|c|c|c|}
\hline \multicolumn{1}{|c|}{ Reservoir } & Order & Family & Genus & Species & Percentage \\
\hline Serepok & 3 & 13 & 18 & 34 & 53.97 \\
\hline Buon Kuop & 3 & 13 & 22 & 54 & 85.71 \\
\hline Buon Tua Srah & 3 & 14 & 23 & 55 & 87.3 \\
\hline Total & 3 & 15 & 23 & 63 & 100 \\
\hline
\end{tabular}

To assess the biodiversity of these reservoirs, the species accumulator and species richness estimators were constructed using the rarefaction method and fitted with a logarithmic model. The result showed that the average number of species at each studied site was relatively high (about 36 species/sample).
Besides, the number of species increased with the sample size following the equation $y=$ $36.35+13.01 \log (x)\left(\mathrm{R}^{2}=0.93\right)$. Based on the estimators, the species richness of rotifers in reservoirs might be between 63-65 taxa (according to the Chao 2, Jacknife 2 and Bootstrap indices) (Figure 3).

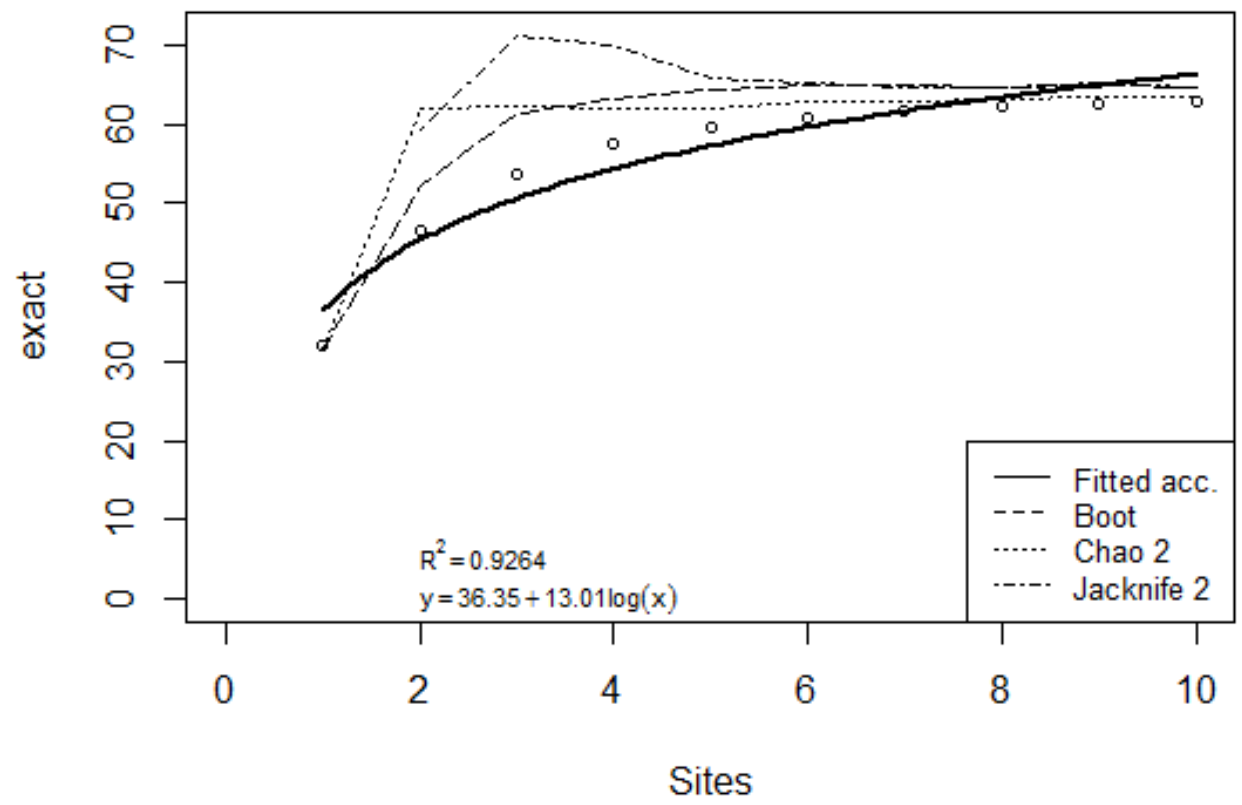

Figure 3. Species accumulator of species richness at study sites, with fitted curve and estimator curves

Jaccard's similarity index was calculated in order to investigate the similarities between rotifera communities among three reservoirs of Western highlands (Table 3). The highest value of similarity index was found between Buon Kuop reservoir and Buon Tua Srah reservoir (similarity index $=0.85$ ) while Serepok reservoir was quite different from the rest (similarity index $<0.5)$. 
Table 3. The similarity index of rotifer communities among sites

\begin{tabular}{|l|c|c|c|}
\hline \multicolumn{1}{|c|}{ Sites } & $(1)$ & $(2)$ & (3) \\
\hline Serepok (1) & 1 & & \\
\hline Buon Kuop (2) & 0.40 & & \\
\hline Buon Tua Srah (3) & 0.47 & 0.85 & 1 \\
\hline
\end{tabular}

Table 4. The similarity index of the rotifer communities among areas

\begin{tabular}{|l|c|c|c|c|c|c|c|c|}
\hline \multicolumn{1}{|c|}{ Sites } & $(1)$ & $(2)$ & (3) & (4) & (5) & (6) & (7) & (8) \\
\hline Khanh Hoa Province (1) & 1 & & & & & & & \\
\hline Southern Vietnam (2) & 0.34 & & & & & & & \\
\hline Như Y River (3) & 0.37 & 0.31 & & & & & & \\
\hline Thuy Tien Lake (4) & 0.24 & 0.19 & 0.33 & & & & & \\
\hline Bau Thiem Lake (5) & 0.09 & 0.08 & 0.11 & 0.24 & & & & \\
\hline Phu Ninh Lake (6) & 0.32 & 0.31 & 0.29 & 0.32 & 0.17 & & & \\
\hline Ly Son Island (7) & 0.19 & 0.12 & 0.2 & 0.17 & 0.11 & 0.15 & & \\
\hline Western Highlands (8) & 0.41 & 0.32 & 0.37 & 0.45 & 0.19 & 0.46 & 0.22 & 1 \\
\hline
\end{tabular}

Moreover, the similarities on the species composition of the rotifera community in this study was compared to those of other freshwater bodies in Vietnam (Table 4). Results fluctuated in the range of $0.19-0.46$, demonstrating low to intermediate similarities. In particular, the highest similarity was found between the reservoirs in western highlands and Phu Ninh lake, a mesotrophic habitat located in northern Quang Nam Province (Trinh-Dang et al., 2019b) with a value of 0.46 , followed by Thuy Tien lake in Hue (Trinh-Dang et al., 2013) and reservoirs in Khanh Hoa Province (Zhdanova, 2011) with values of 0.45 and 0.41 respectively. The largest difference in species composition was observed between this studied area and Bau Thiem lake, an oligotrophic habitat in Thua Thien Hue Province (Trinh-Dang et al., 2015) with dissimilarity index of 0.81 , followed by water bodies in Ly Son island (Vo et al., 2019) with dissimilarity index of 0.78 (Table 4). These differences may be due to the difference of water body characteristics. In general, reservoirs in western highlands are oligotrophic habitats, indicated by $\mathrm{Q}_{\mathrm{B} / \mathrm{T}}$ index values $<1$ except Serepok reservoir (mesotrophic - $\mathrm{Q}_{\mathrm{B} / \mathrm{T}}$ index $=1.3$ ). According to on-field observations, aquaculture activities at Serepok reservoir has risen rapidly in recent years, which may cause the decline of biodiversity. Therefore, it is necessary to conduct further studies on water quality and biodiversity of this lake in order to develop appropriate management strategies.

\section{CONCLUSION}

In summary, a total of 63 species and subspecies representing 23 genera in 15 families were reported. Of these, the Brachionidae is the most diverse family with 15 taxa recorded $(23.81 \%)$ followed by Lecanidae (14 taxa, 22.22\%), and Synchaetidae (8 taxa, 12.7\%). The number of species increased with the sample size, following the equation $y=36.35+$ $13.01 \log (x)\left(\mathrm{R}^{2}=0.93\right)$. In comparison to other areas of Vietnam, the recorded faunal composition of western highlands was relatively similar (with similarity index value ranging from 0.19 to 0.46 ). In particular, the highest similarity was found between western highlands and Phu Ninh lake. The largest difference in species composition was observed between western highlands and Bau Thiem lake.

\section{REFERENCES}

Dang N. T., Thai T. B., Pham V. M., 1980. Classification of freshwater invertebrates in Northern Viet Nam. Artic. Vietnam. Sci. Publ. House Ha Noi. (Vietnamese). 
Dussart B.H., Fernando C.H., MatsumuraTundisi T., Shiel R.J., 1984. A review of systematics, distribution and ecology of tropical freshwater zooplankton, in: Tropical Zooplankton. Springer, pp. 7791. https://doi.org/10.1007/978-94-0173612-1_5

Oksanen J., Blanchet F.G., Kindt R., Legendre P., Minchin P.R., O'hara R.B., Simpson G.L., Solymos P., Stevens M.H.H., Wagner H., 2013. Package 'vegan.' Community Ecol. Package Version 2, 1-295.

Phan D.D., Le N.N., 2012. Diversity on Rotifera species competitions in fresh inland waters of Southern Vietnam and some new records for zooplankton fauna of Vietnam. J. Biol. Vietnam, 34: 13-20. (Vietnamese).

Sanoamuang L., Savatenalinton S., 2001. The rotifer fauna of Lake Kud-Thing, a shallow lake in Nong Khai Province, northeast Thailand, in: Rotifera IX. Springer, pp. 297-304. https://doi.org/ 10.1023/A:1017588331347

Segers H., 2007. Annotated checklist of the rotifers (Phylum Rotifera), with notes on nomenclature, taxonomy and distribution. Zootaxa, 1564: 1-104. https://doi.org/ 10.11646/zootaxa.1564.1.1

Segers H., 2001. Zoogeography of the southeast Asian Rotifera, in: Rotifera IX. Springer, pp. 233-246. https://doi.org/ 10.1007/978-94-010-0756-6_32

Shirota A., 1966. The plankton of South VietNam: freshwater and marine plankton. Overseas Technical Cooperation Agency.

Sládeček V., 1983. Rotifers as indicators of water quality. Hydrobiologia, 100: 169 201. https://doi.org/10.1002/aheh.19870 150507
Team R.C., 2013. R development core team. RA Lang Env. Stat Comput 55, 275-286.

Trinh-Dang M., Phan D.D., Vo V.M., 2019a. A new rotifer species: Lecane langsenensis $\quad n$. $\quad$ sp.(Rotifera: Monogononta) from Vietnam. Zootaxa, 4615: 155-164. https://doi.org/ 10.11646/zootaxa.4615.1.8

Trinh-Dang M., Segers H., Sanoamuang L., 2013. Rotifers from Thuy Tien lake and Nhu Y river in central Vietnam, with a description of Ploesoma asiaticum new species (Rotifera: Monogononta). $J$. Limnol., 72: e19. https://doi.org/ 10.4081/jlimnol.2013.s2.e19

Trinh-Dang M., Segers H., Sanoamuang L.O., 2015. Psammon rotifers in Central Vietnam, with the descriptions of three new species (Rotifera: Monogononta). Zootaxa, 4018: 249-265. https://doi.org/ 10.11646/zootaxa.4018.2.5

Trinh-Dang M., Van Vo M., Tran A.N.Q., Le H.N.T., Tran S.N., 2019b. Species diversity of rotifers (Rotifera: Eurotatoria) of Phu Ninh Lake with five new records from Vietnam. Int. J. Aquat. Biol., 7: 3844. https://doi.org/10.22034/ijab.v7i1.581

Vo V.M., Trinh-Dang M., Tran N.Q.A., Tran N.S., Duong-Quang H., 2019. Species diversity of Rotifers (Rotifera: Monogononta) from Ly Son island with a new record for Vietnam. Univ. Danang $J$. Sci. Technol., 17: 40-42. https://doi.org/ 10.31130/jst-ud2019-161e

Zhdanova S.M., 2011. The species composition of rotifers in the water reservoirs of Central Vietnam. Inland Water Biol., 4: 425-434. https://doi.org/ 10.1134/S1995082911030205 